\title{
A Review of Factors of Customer Relationship Management and their Impact on Hotel Performance
}

\author{
Osama Omar Abobakr Abdulkaber ${ }^{1}$, K. Ramanthan Kalimuthu² \\ Post Graduate Center, Limkokwing University of Creative Technology ${ }^{1,2}$
}

\begin{abstract}
Customer Relationship Management (CRM) has a growing popularity and is becoming one of the hottest academic and practical topics in the business field. In fact, due to the competitive environment, CRM is crucial and has become a niche for firm performance. CRM can bring many benefits to the hotel business, though there are some associated challenges. Such challenges often bring a significant risk of failure, and these risks become more significant in budget hotels. However, there is limited research that reveals the relationship between CRM dimensions and hotel performance. Therefore this review study is an attempt to provide a literature review that explains the factors of CRM towards performance and the theoretical linkages existing between CRM dimensions and hotel performance. This study serves not only to clarify the relationship between CRM dimensions and hotel performance, but also to explain role of marketing capabilities in this relationship.
\end{abstract}

Keywords: Customer Relation Management (CRM), Hotel Industry, Customer Satisfaction, Literature Review

\section{INTRODUCTION}

Undoubtedly, CRM has recently become among the very contentious issues and a focal point at the business field [1, 2 , \& 3]. It's worth mentioning that CRM is principally predicated on the fact setting a more sustainable relationship with customers is the cornerstone for obtaining loyal customers that are much more profitable than non -loyal ones [4]. In this regard, the effective implementation of CRM strategy is going to be of excellent advantage to the organizations, embracing it, as such organizations may reap the benefits of increasing earnings through improved market segmentation, customizing products and services, receiving higher quality products, gaining use of information and employee satisfaction, and most importantly, ensuring long-lasting customer-retention and loyalty [5, 6, 7, \& 8]. Furthermore, we have to keep in mind the recent studies around the CRM selectively focus on several service industries, such as banking and hospitality $[9,10, \& 11]$, healthcare $[12,14]$. Consequently, there is still a noticeable absence of research about CRM from the hospitality industry [13, 15]. Therefore, it is not a surprise to locate Vogt's highlighting this concept. He says, even though there's ever-increasing usage of CRM in the tourism sector, there continue to be limited researches investigating its variety of software from such significant industry [16]. Additional several researches refer to the value of making studies on CRM measurements in the hotel sector [17, 5]. As a result of the, it's sensible to lead in conclusion it is not only almost no attention has been given into the CRM measurements within the hotel industry, but there is also plenty of opportunity for expanding the literature around CRM dimensions and hotel performance, both theoretically and empirically.

\section{LITERATURE REVIEW}

\section{a. Customer Relationship Management (CRM)}

It is worth noting that the Concept of CRM may be defined in different ways. It means things To various people in [10]. For that reason, there's no single correct definition of CRM [13] But to improve the literature in CRM, This study will define it as a tactical approach that empowers Organizations to make utilize of internal resources (i.e. Technology, people, and process) To deal with the relationship with customers for all of their lives cycles, As a way to develop a competitive advantage and enhance an organization's performance.

\section{b. $\quad$ CRM and Hotel Industry}

Inspite of the undeniable fact CRM brings lasting advantages to organizations, as a complete, a few of them benefit benefits from implementing it over many others; CRM brings benefits to those organizations which generate a whole good deal of advice regarding customers [15]. Service organizations to get their inherent characteristics of the creation and ingestion are inseparable elements essential to create relationships with customers [16]. CRM will probably likely be ideally suitable for this hotel business if implementing this taking that hotels are given a whole good deal of data on customers. Such data might be converted to useful knowledge regarding these [18, $19 \& 20]$. Suffice it to state hotel 
business, for example every business sector must become highly competitive in order to succeed in the company environment, so it's of crucial significance in order for this to encourage behavioral patterns of continuous re purchase also to maintain customers continue longer. Thus, it's clear that such ambitious goals can only be done through implementing CRM, that will result in establishing profitable relationship between organizations and their customers $[21,22]$. It goes without mentioning that customer- acquisition prices, rising customer expectations travellers, even more customers market and brand loyalty are factors, that advocate hotels to concentrate being a more strategy that is beneficial. Needless to say CRM is widely thought of one among the best tactics to facilitate growing and enlarging your customers' base which, in turn, can help in improving endurance and guest loyalty [23, 25].

\section{c. Hotel performance}

CRM measurements evaluation has been evaluated in lots of ways, for example customer satisfaction [21, 24] promote efficacy and fiscal performance [20], customer performance and fiscal performance [6], and customer retention and earnings increase [25]. The employment of different measurements of performance is equally effective since indicated by previous studies [24]. For that reason, this study uses the Balance score card (BSC) measurements to value the effect of how CRM measurements on hotel performance. The current study utilizes a Balance scorecard (BSC) measurement to appraise hotel performance because financial amounts can't offer the complete comprehension of CRM impact and result and so the entire performance outlook ought to be employed at the test of CRM results [25]. Additionally, existing literature shows that the utilization of balanced score card (BSC) to rate the effect of CRM on firm performance is crucial as it's a beneficial tool to offer an in-depth comprehension of firm's overall functionality performance [24].

\section{d. Marketing -planning capabilities}

In actuality, literature about organizational capabilities has signaled a positive relationship between capabilities in general, and business performance [26]. For that reason, it's not accidental that [25] defines marketing planning capacities as the firm's capability to anticipate and react to the changes in the market environment for the purpose of directing its resources actions to focus on the alignment of the company with the environment and the achievement of organizational financial targets. Hence, [26] find out that marketing -going capacities have a favorable influence on the firm's performance. In this aspect, [26], [27] say that developing marketing-capabilities will result in better organizational performance. In the same way, Kumar et al., [25] conclude that both technical and architectural marketing capabilities are affected by organizations business plans. Most of all, these kinds of marketing abilities and their integration are important drivers of market efficacy. Therefore, customer-centric strategies help determine the marketing capacities of these organizations and contributes to improved organizational performance. In addition, Cambra [28] argue that marketing -planning capabilities allow organizations to embrace a market orientation or customer orientation approaches and take proper actions so. In this regard, Colomo et al. [27], admits that market orientation is still operating in association with marketing abilities to generate economic profitability, and could possibly be considered as a source of competitive edge. Furthermore, the collaboration between the organization's customer orientation and its marketing abilities is positively linked to its business performance, since it leads to the creation of casual ambiguity, which makes it hard for competitors to ascertain the business's competitive advantage [30]. Moreover, many studies also have found that marketing planning capacities have a favorable influence on organizational performance [26].

\section{DISCUSSION}

At the business ecosystem, hotels not merely have to determine the criteria of its target guests but also aim to excel at these whether it really would be to outperform its competitors and retain the attention of its existing and potential guests. Considering the challenges of implementing CRM projects with limited resources of budget hotels it can urge that budget hotels rather than devoting their product and services should concentrate for cash for guest's satisfactions and retention. Though it needs to be considered that the people (organizational culture changes) and process (Business Proses engineering) section of CRM application can facilitate the processes and guest requests, which is one of those customer satisfaction criteria.

\section{CONCLUSION AND RECOMMENDATION}

This study has provided a review to reveal the business relationship between CRM measurements, marketing capacities and hotel performance. It leads into your human body of comprehension, because it gives a framework that's utilized for describing these four dimensions' effects to hotel performance. It's a recognized fact that the concept of customer relationship management has been verified, nor assessed to ascertain the effectiveness of this relationship between measurements of customer-relationship management and hotel industry performance. What's more, this study effectively expands the body of knowledge from explaining the theoretical chances of this role of marketing capacities 


\title{
International Advanced Research Journal in Science, Engineering and Technology
}

\author{
Vol. 6, Issue 2, February 2019
}

(preparation and execution) from the relationship between CRM measurements and hotel performance. It's well worth mentioning that paper may raise awareness among hotel managers to invest focus on CRM measurements, marketing capabilities, and also assist them in improving hotel performance and validity. The simple fact remains that study has its own limits.

\section{REFERENCES}

[1]. Abdullateef, A.O., Mokhtar, S.S., Yusoff, R.Z. (2010), The impact of CRM Dimensions on Call Center Performance. International Journal of Computer Science and Network Security, 10(12), 184-195.

[2]. Akroush, N.M., Dahiyat, E.S., Gharaibeh, S.H., Abu-Lail, N.B. (2016), Customer relationship management implementation. An investigation of a scale's generalizability and its relationship with business performance in a eveloping country context. International Journal of Commerce and Management, 21(2), 158-191.

[3]. Almotairi, M. (2009), A Framework for CRM Success. Proceedings of the European and Mediterranean Conference on Information Systems 2009. Izmir, Turkey, 13-14 July.

[4]. Asikhia, O. (2010), Customer Orientation and Firm Performance among Nigerian Small and Medium Scale Businesses. International Journal of Marketing Studies, 2(1), 197-213.

[5]. Azizi, S., Movahed, A.S., Khah, H.M. (2009), Medical Equipment Sector. The Effect of Marketing Strategy and Marketing Capability on Business Performance. Case Study: Iran's Medical Equipment Sector. Journal of Medical Marketing, 9(4), 309-321.

[6]. Balaram, A., Adhikari, B. (2010), Managing Customer Relationships in Service Organizations. Administration and Management Review, 21(2), 65-78

[7]. Baran, R. J., Galka, R., Strunk, P. D. (2008), Principles of customer Relationship Management. U.S.A: Thomson. Barney, B.J., Delwyn, N. (2007), Resource-Based Theory: Creating and Sustaining Competitive Advantage. Oxford: Oxford University Press.

[8]. Becker, U.J., Greve, G., Albers, S. (2009), The impact of technological and organizational implementation of CRM on customer acquisition, maintenance, and retention. International Journal of Research in Marketing, 26(3), 207-215.

[9]. Beldi, A., Cheffi, W., Dey, B. (2010), Managing customer relationship management projects: The case of a large French telecommunications company. International Journal of Project Management, 28(4), 339-351.

[10]. Bose, R. (2002), Customer Relationship Management: key components for IT success. Industrial Management and Data Systems, 102(2), 8997.

[11]. Boulding, W., Staelin, R., Ehret, M., Johnston, W. J. (2005), A customer relationship management roadmap: what is known, potential pitfalls, and where to go. Journal of Marketing, 69(4), 155- 66

[12]. Bunthuwun, L., Sirion, C., Howard, C. (2011), Effective Customer relationship management of health care: A study of the perceptions of service quality, cooperate image, satisfaction, and loyalty of that outpatients of private hospital in Thailand. ASBBS Annual Conference: Las Vegas, February, 17(1), 198-211.

[13]. Chang, W., Park, E.J., Chaiy, S. (2010), How does CRM technology transform into organizational performance? A mediating role of marketing capability. Journal of Business Research, 63, 849- 855

[14]. Cizmar, S., Weber, S. (2000), Marketing effectiveness of the hotel industry in Croatia. International Journal of Hospitality Management, 19(3), 227-240.

[15]. Dutu, C., Halmajan, H. (2011), The Effect of Organizational Readiness on CRM and Business Performance. International Journal of Computers, 1(2), 106-114.

[16]. Eid, R. (2017), Towards a Successful CRM Implementation in Banks: An Integrated Model. The Service Industries Journal, $27(8), 1021-1039$.

[17]. Fan, Y., Ku, E. (2010), Customer focus, service process fit and customer relationship Management profitability: the effect of knowledge sharing. The Service Industries Journal, 30(2), 203-222.

[18]. Hallin, C.A., Marnburg, E. (2008), Knowledge management in the hospitality industry: a review of empirical research. Tourism Management, $29(2), 366-81$

[19]. Hamid, H. (2009), Toward unfolding CRM implementation in Pakistan: A case study. 17th European Conference on Information Systems. Islamabad, Pakistan. Retrieved June 28,2011,from http://is2.1se.ac.uk/asp/aspecis/20090249.pdf

[20]. Kasim, A., Minai, B. (2009), Linking CRM strategy, customer performance measure and performance in hotel industry. International Journal of Economics and Management, 3(2), $297-316$.

[21]. Reimann, M., Schilke, O., Thomas, J. (2010), Customer relationship management and firm performance: the mediating role of business strategy. Journal of the Academy Marketing Science, 38, 326-346

[22]. Priya, G., Jyoti, K., \& et.al., (2013). Customer Relationship Mangement: A Tool of Converting Customer Need into Business Opportunities", The Indian Journal of Commerce, 66(1), 43-59.

[23]. Rajesh, V., and Manivannan, L., (2013): “A Study on Customer Relationship Management in Bank of Baroda, with Special Reference to Erode City of Tamilnadu, India”, Wide Spectrum Research Journal, 1(11),45-50.

[24]. Rozita Shahbha, K., (2012). The Impact of E-CRM on Customers Attitude and Its Association with Generating Competitive Advantages in Iranian Financial B2B Market. International Business Research, 5(4), 34-54.

[25]. Saroj Kumar, D., and Arun Kumar, P., (2011). Managing Customer Relationships in Private Health Care Facilities - A Study with Reference to Greater Noida City of Uttar Pradesh. Serbian Journal of Management, 6(1), $27-42$.

[26]. Abdul Alem Mohammed, Basri B. Rashid and Shaharuddin B. Tahir. (2017) Customer relationship management and hotel performance: the mediating influence of marketing capabilities_ evidence from the Malaysian hotel industry. Information Technology \& Tourism 17:3, 335-361. Online publication date: $10-$ Apr-2017.

[27]. Ricardo Colomo-Palacios, Francisco Jos? Garc?a-Pe?alvo, Vladimir Stantchev and Sanjay Misra. (2017) Towards a social and context-aware mobile recommendation system for tourism. Pervasive and Mobile Computing 38, 505-515. Online publication date: 1-Jul-2017.

[28]. Jesús Juan Cambra-Fierro, Edgar Centeno, Ana Olavarria and Rosario Vazquez-Carrasco. (2017) Success factors in a CRM strategy: technology is not all. Journal of Strategic Marketing 25:4, 316-333. Online publication date: 21-Mar-2016.

[29]. Antonia Estrella-Ramón, Manuel Sánchez-Pérez, Gilbert Swinnen and Koen VanHoof. (2017) A model to improve management of banking customers. Industrial Management \& Data Systems 117:2, 250-266. Online publication date: 13-Mar-2017.

[30]. Robert J. Harrington, Michael C. Ottenbacher and Simon Fauser. (2017) QSR brand value. International Journal of Contemporary Hospitality Management 29:1, 551-570. Online publication date: 9-Jan-2017.

[31]. Amanda Let?cia Pit Nunes, Otavio Jorge Grigoli Abi-Saab and Ricardo Ralisch. (2017) Customer relationship management in the agricultural machinery market. Ci?ncia Rural 47:7. Online publication date: 1-Jan-2017. 